\title{
Pendidikan Kewarganegaraan untuk Sekolah Menengah Pertama: Tinjauan Filosofis, Sosiologis, Yuridis, dan Psikologis
}

\author{
Budi Mulyono ${ }^{a, 1^{*}}$ \\ ${ }^{a}$ Universitas Negeri Yogyakarta, Yogyakarta \\ ${ }^{1}$ budi.mulyono@uny.ac.id \\ ${ }^{*}$ Korespondensi penulis
}

\begin{abstract}
ABSTRAK
Artikel ini membahas tentang Pendidikan Kewarganegaraan yang diselenggarakan di jenjang Sekolah Menengah Pertama (SMP) dilihat dari tinjauan filosofis, sosiologis, yuridis, dan psikologis.Sebagai program kurikuler, pendidikan Kewarganegaraan menjadi satu mata pelajaran di sekolah dasar dan menengah yang memiliki tugas profesional untuk membina siswa agar menjadi generasi penerus yang sebagaimana diharapkan bangsa dan negara dalam konteks pembinaan generasi muda menjadi seorang warga negara yang baik. Oleh karenanya pendidikan kewarganegaran khususnya di jenjang SMP mengemban misi nasional untuk mencerdaskan kehidupan bangsa Indonesia melalui koridor "value based education". Secara filosofis pendidikan kewarganegaraan memiliki visi holistik-eklektis yang memadukan secara serasi pandangan perenialisme, esensialisme, progresifisme, dan sosiorekonstruksionisme dalam konteks keindonesiaan. Secara sosiologis, dalam teori perkembangan sosial Ericson anak usia SMP berada pada tingkat tingkat 5, Identity vs Role Confusion, dimana remaja sedang dalam usaha sedang mencari jati dirinya. Anak-anak remaja perlu diberi kesempatan untuk mengeksplorasi berbagai cara untuk memahami identitas dirinya. Secara yuridis, Menurut Permendikbud No. 58 Tahun 2014, secara umum tujuan mata pelajaran Pendidikan Pancasila dan Kewarganegaraan pada jenjang pendidikan dasar dan menengah adalah mengembangkan potensi peserta didik dalam seluruh dimensi kewarganegaraan, yakni: (1) sikap kewarganegaraan termasuk keteguhan, komitmen, dan tanggungjawab kewarganegaraan (civic confidence, civic committment, and civic responsibility); (2) pengetahuan kewarganegaraan; (3) keterampilan kewarganegaraan termasuk kecakapan dan partisipasi kewarganegaraan (civic competence and civic responsibility). Secara psikologis, masa remaja awal (Usia SMP) sudah mencapai tahap operasi formal. Pada usia ini secara mental anak telah dapat berpkir logis tentang berbagai gagasan yang abstrak. Dengan kata lain, berpikir operasi formal lebih bersifat hipotesis dan abstrak serta sistematis dan ilmiah dalam memecahkan masalah daripada berpikir konkrit.
\end{abstract}

Kata kunci: pendidikan, kewarganegaraan, sekolah menengah pertama

\begin{abstract}
This article discusses Citizenship Education held at the level of Junior High School (SMP) seen from philosophical, sociological, juridical, and psychological reviews. As a curricular program, Citizenship education becomes a subject in primary and secondary schools that has professional assignments to foster students in order to become the next generation that as expected by the nation and state in the context of fostering the young generation to become a good citizen. Therefore citizenship education especially at the junior high school level carries out a national mission to educate the life of the Indonesian nation through a corridor of "value based education". Philosophically, civic education has a holistic-eclectic vision that harmoniously combines the views of perennialism, essentialism, progression, and socialism in the context of Indonesian-ness. Sociologically, in the theory of social development Ericson middle school age children are at level 5, Identity vs. Role Confusion, where teenagers are in business looking for their identity. Teenagers need to be given the opportunity to explore various ways to understand their identity. Juridically, according to Minister of Education and Culture No. 58 of 2014, the general goal of Pancasila and Citizenship Education subjects at the level of primary and secondary education is to develop the potential of students in all dimensions of citizenship, namely: (1) citizenship attitudes including persistence, commitment, and civic confidence, civic commitment, and civic responsibility); (2) citizenship knowledge; (3) citizenship skills including civic competence and civic responsibility. Psychologically, early adolescence (Middle School age) has reached the stage of formal operation. At this age the child can mentally think logically about various abstract ideas. In other words, thinking formal operations are more hypothetical and abstract and systematic and scientific in solving problems rather than concrete thinking.
\end{abstract}

Keywords: education, citizenship, junior high school

Copyright (C2018 Universitas Ahmad Dahlan, All Right Reserved

\section{PENDAHULUAN}

Pendidikan kewarganegaraan merupakan salah satu mata pelajaran yang wajib diselenggarakan di setiap jenjang pendidikan, sebagai pedoman dalam pelaksanaan proses pembelajaran sebagaimana diamanatkan Undang-undang Nomor 20 Tahun 2003 tentang Sistem Pendidikan Nasional, salah satunya adalah jenjang pendidikan menengah pertama (SMP). Mata pelajaran ini memfokuskan pada pembentukan warga negara yang cerdas, 
terampil, berkarakter, dan berbudi pekerti yang luhur sesuai dengan amanat Pancasila dan UUD 1945.

Sebagai program kurikuler, pendidikan Kewarganegaraan menjadi satu mata pelajaran di sekolah dasar dan menengah yang memiliki tugas profesional untuk membina siswa agar menjadi generasi penerus yang sebagaimana diharapkan bangsa dan negara dalam konteks pembinaan generasi muda menjadi seorang warga negara yang baik. Anak adalah warga negara hipotetik, yakni warga negara yang "belum jadi" karena masih harus dididik menjadi warga negara dewasa yang sadar akan hak dan kewajibannya (Budimansyah, 2007, hal. 11). Sebagai program pendidikan, PKn memiliki lingkup yang cukup luas dan meliputi setidaknya tiga domain dalam proses pembentukan karakter, yakni (1) secara konseptual PKn berperan dalam mengembangkan konsep-konsep dan teori; (2) secara kurikuler PKn mengembangkan sejumlah program pendidikan dan model implementasinya dalam mempersiapkan peserta didik menjadi manusia dewasa yang berkarakter melalui lembagalembaga pendidikan; dan (3) secara sosio kultural PKn melaksanakan proses pembelajaran kepada masyarakat agar menjadi warga negara yang baik (Sapriya, 2007, hal. 5).

Oleh karenanya pendidikan kewarganegaran khususnya di jenjang SMP mengemban misi nasional untuk mencerdaskan kehidupan bangsa Indonesia melalui koridor "value based education". Konfigurasi atau kerangka sistematik PKn dibangun atas dasar paradigma. Paradigma yang pertama $\mathrm{PKn}$ secara kurikuler diracang sebagai subjek pembelajaran yang bertujuan untuk mengembangkan individu agar menjadi warga negara yang berakhlak mulia, cerdas, partisipatif dan bertanggung jawab. Kedua PKn secara teoritik dirancang sebagai subjek pembelajaran yang memuat dimensi-dimensi kognitif, efektif dan psikomotrik, yang ketiga PKn secara paragramatik dirancang sebagai subjek pembelajaran yang menekankan pada isi yang mengusung nilai-nilai (content embedding value) dan pengalaman belajar (learning experiences).

Secara konseptual, ada dua rumusan mengenai pendidikan kewarganegaraan dalam kosa kata bahasa Inggris yaitu civics education dan citizenship education. Kedua konsep ini diterjemahkan sama dalam bahasa Indonesia, meskipun sebenarnya kedua istilah tersebut berbeda pengertiannya. Edmonson (1958) merumuskan arti Civics dengan Civics is usually defined as the study of goverment of citizenship, that is, of the duties, right and privilages of citizens. Batasan ini menunjukkan bahwa Civics merupakan cabang dari ilmu politik. Hal ini pula dapat dibaca dalam Dictionary of Education sebagai berikut Civics (is) the element of political science or that branch of political science dealing with the right and duties of the citizens. Arti Civics dalam perkembangan selanjutnya bukan hanya meliputi goverment saja, melainkan kemudian ada yang disebut community civics, economics civics atau vocational civics. Dengan demikian hampir semua definisi mengenai Civics pada intinya menyebut goverment, hak dan kewajibannya sebagai warga dari sebuah negara (Ubaidillah \& Rozak, 2003, hal. 5) Sedangkan Branson dan Quigley mendefinisikan Civic Education sebagai:

"Civic Education in a democracy is education in self government. Democratic self government means that citizens are actively involved in their own governance; they do not just passively accept the dictums of others or acquiesce to the demands of others" (Branson \& Quigley, 1998, hal. 4).

Maksudnya Civic Education dalam demokrasi adalah pendidikan untuk mengembangkan dan memperkuat dalam atau tentang pemerintahan otonom (self-government). Pemerintahan otonom demokratis berarti bahwa warga negara aktif dalam pemerintahannya sendiri; mereka tidak hanya menerima didikte orang lain atau memenuhi tuntutan orang lain. Istilah lain yang hampir sama maknanya dengan Civics adalah Citizenship. Dalam hubungan ini Stanley E. Demond (Somantri, 2001, hal. 282) menjelaskan rumusan Citizenship sebagai berikut:

"Citizenship as it relates to school activities has twofold meaning. In a narrow-sense, citizenship includes only legal status in country and the activities closely related to the political function-voting, governmental organization, holding of office and legal right and responsibility".

Mata pelajaran PKn memiliki visi, misi, dan tujuan yang mengarah pada pembentukan warga negara yang baik dan bertanggung jawab sebagai wujud perilaku dalam kehidupan berdasarkan nilainilai yang terkandung dalam dasar negara Pancasila. Melalui PKn ini, pendidikan ketaatan hukum merupakan muara sebagai bentuk aktualisasi dari demokrasi. Dengan begitu, masyarakat dapat memahami dan menyadari betapa pentingnya tunduk dan patuh terhadap hukum yang berlaku tersebut sebagai wujud dari adanya demokrasi dan upaya dalam membentuk masyarakat yang sejahtera.

Secara historis, epistemologis dan pedagogis, Pendidikan Kewarganegaraan berkedudukan sebagai program kurikuler dimulai dengan diintroduksikannya mata pelajaran Civics dalam kurikulum SMA dan SMP tahun 1962 yang berisikan materi tentang pemerintahan Indonesia berdasarkan Undang-Undang Dasar 1945. Pada saat 
itu, mata pelajaran Civics atau kewarganegaraan, pada dasarnya berisikan pengalaman belajar yang digali dan dipilih dari disiplin ilmu sejarah, geografi, ekonomi, dan politik, pidato-pidato presiden, deklarasi hak asasi manusia, dan pengetahuan tentang Perserikatan Bangsa-Bangsa (Somantri, 2001, hal. 298). Istilah tersebut secara formal tidak dijumpai dalam kurikulum tahun 1946 namun secara materil kurikulum SMP tahun 1957 terdapat mata pelajaran Tata Negara dan Tata Hukum. Dan dalam kurikulum 1946 terdapat pelajaran pengetahuan umum yang di dalamnya memasukkan pengetahuan mengenai pemerintahan (Winataputra, 2015, hal. 154).

Kemudian dalam kurikulum tahun 1968 istilah civics dan Pendidikan Kewargaan Negara digunakan secara bertukar-pakai (interchangeably). Dalam kurikulum SMP tahun 1968 digunakan istilah Pendidikan Kewargaan Negara yang dipakai sebagai nama mata pelajaran, yang di dalamnya mencakup sejarah Indonesia, geografi Indonesia, dan civics (diterjemahkan sebagai pengetahuan kewargaan negara).

Pada Kurikulum tahun 1975 istilah Pendidikan Kewargaan Negara diubah menjadi Pendidikan Moral Pancasila (PMP) yang berisikan materi Pancasila sebagaimana diuraikan dalam Pedoman Penghayatan dan Pengamalan Pancasila atau P4. Perubahan ini sejalan dengan misi pendidikan yang diamanatkan oleh Tap. MPR IV/MPR/1973. Mata pelajaran PMP ini merupakan mata pelajaran wajib untuk SD, SMP, SMA, SPG dan Sekolah Kejuruan. Mata pelajaran PMP ini terus dipertahankan baik istilah maupun isinya sampai dengan berlakunya Kurikulum 1984 yang pada dasarnya merupakan penyempurnaan dari Kurikulum 1975 (Winataputra, 2015, hal. 156). Pendidikan Moral Pancasila (PMP) pada masa itu berorientasi pada value inculcation dengan muatan nilai-nilai Pancasila dan UUD 1945. Seiring dengan perkembangan kebijakan politik di Indonesia maka PMP diganti dengan Pendidikan Pancasila dan Kewarganegaraan (PPKn) pada tahun 1994. Berbeda dengan kurikulum sebelumnya, kurikulum PPKn 1994 menggunakan pengorganisasian materi pembelajarannya bukan atas dasar rumusan butirbutir nilai P4, tetapi atas dasar konsep nilai yang disaripatikan dari $\mathrm{P} 4$ dan sumber resmi lainnya yang ditata menggunakan pendekatan pengorganisasian kurikulum spiral meluas atau spiral of concept development.

Selanjutnya setelah bergulirnya Reformasi, pada kurikulum 2004 dan kurikulum 2006 istilah PPKn diubah menjadi Pendidikan Kewarganegaraan. Akan tetapi, pada kurikulum 2013, nomenklatur Pendidikan Kewarganegaraan dikembalikan lagi menjadi Pendidikan Pancasila dan Kewarganegaraan.

Dari pemaparan ini, jelas sekali tugas dan tanggungjawab pendidikan kewarganegaraan khususnya dalam jenjang sekolah menengah pertama (SMP) tidaklah mudah. Akan tetapi, dinamika politik dan sosial dan negara, turut menentukan bagaimana program pendidikan kewarganegaraan diberlakukan secara kurikuler di sekolah. Untuk itu, dibutuhkan kajian secara filosofis, sosiologis, yuridis, dan psikologis tentang pendidikan kewarganegaraan untuk jenjang SMP untuk menjadi kajian ilmiah yang komprehensif dalam membahas kebutuhan PKn di SMP.

Berdasarkan latar belakang di atas, dapat dibuat beberapa rumusan masalah sebagai berikut:

1. Bagaimanakah tinjauan filosofis PKn SMP?

2. Bagaimanakah tinjauan sosiologis $\mathrm{PKn}$ SMP?

3. Bagaimanakah tinjauan yuridis PKn SMP?

4. Bagaimanakah tinjauan Psikologis PKn SMP?

\section{HASIL DAN PEMBAHASAN}

\section{Tinjauan Filosofis}

Secara filosofis pendidikan kewarganegaraan memiliki visi holistik-eklektis yang memadukan secara serasi pandangan perenialisme, esensialisme, progresifisme, dan sosiorekonstruksionisme dalam konteks keindonesiaan (Winataputra, 2015, hal. 281). Secara sosiopolitik dan kurltural pendidikan kewarganegaraan memiliki visi pendidikan untuk mencerdaskan kehidupan bangsa yakni menumbuhkembangkan kecerdasan kewarganegaraan (civic intelligence) yang merupakan prasarat untuk pembangunan demokrasi dalam arti luas, yang mempersyaratkan terwujudnya budaya kewarganegaraan atau civic culture sebagai salah satu determinan tumbuh-kembangnya negara demokrasi. Konsep ini menurut winataputra (2015, hal. 282) dengan mengutip Hartonian (1992) sebagai makna implikatif dari konsepsi pendidikan kewarganegaraan sebagai integrated knowledge system.

Bertolak dari visinya tersebut, maka pendidikan kewarganegaraan mengemban misi yang bersifat multidimensional (Winataputra, 2015, hal. 282) yakni: (1) misi psikopedagogis, yakni misi untuk mengembangkan potensi peserta didik secara progresif dan berkelanjutan: (2) misi psikososial, yang bertujuan untuk memfasilitasi kematangan peserta didik untuk hidup dan berkehidupan dalam masyarakat negara bangsa, dan (3) misi sosiokultural yang merupakan misi untuk menbangun budaya dan keadaban kewarganegaraan sebagai salah satu determinan kehidupan yang Demokratis. 
Secara konseptual dan holistik (psikologis, pedagogis, dan sosial-kultural) pendidikan kewarganegaraan bertujuan agar setiap warganegara muda/peserta didik (young citizens) memiliki rasa kebangsaan dan cinta tanah air dalam konteks nilai dan moral Pancasila, nilai dan norma UndangUndang dasar Negara republik Indonesia Tahun 1945 , nilai dan komitmen Bhinneka tunggal Ika, dan komitmen bernegara Kesatuan Republik Indonesia. Oleh karena itu secara sadar dan terencana peserta didik sesuai dengan perkembangan psikologis dan konteks kehidupannya secara sistemik difasilitasi untuk belajar berkehidupan demokrasi secara utuh, yakni belajar tentang konsep, prinsip, instrumen, dan praksis demokrasi (learning about democracy), belajar dalam iklim dan melalui proses interaksi sosial, komunikasi, dan kolaborasi secara demokratis (learning through democracy), dan belajar untuk membangun kehidupan demokrasi (learning for democracy) (Kerr, 1999; Winataputra, 2015).

Unsur ontologi Pendidikan Kewarganegaraan memiliki dua dimensi, yakni objek telaah dan objek pengembangan (Winataputra 2001). Objek telaah adalah keseluruhan aspek Idiil, instrumental, dan praksis pendidikan kewarganegaraan yang secara internal dan eksternal mendukung sistem kurikulum dan pembelajaran PKn di sekolah dan di luar sekolah serta format gerakan sosial-kultural kewarganegaraan masyarakat (Budimansyah \& Suryadi, 2008, hal. 19).

Adapun yang dimaksud dengan objek pengembangan atau sasaran pembentukan adalah keseluruhan ranah sosio-psikologis peserta didik, yakni ranah kognitif, afektif, konatif, dan psikomotorik yang menyangkut ststus, hak dan kewajibannya sebagai warganegara, yang perlu dimuliakan dan dikembangkan secara programatik guna mencapai kualitas warga negara yang "cerdas dan baik" dalam arti demokratis, religius dan berkeadaban dalam konteks kehidupan bermasyarakat, berbangsa dan bernegara.

Dalam konteks itu Somantri (Somantri \& Winataputra, 2017, hal. 53) memberi definisi PKn sebagai disipli ilmu dalam konteks PKn sebagai "studi transdisipliner/transdicipliner study" yakni ilmu-ilmu sosial dengan core dicipline-nya ilmu politik, ide fundamental bangsa dan ilmu pendidikan yang diorganisasi dan disajikan secara psikologis dan ilmiah untuk tujuan pendidikan.

Ontologi PKn kini sudah lebih luas dari pada embrionya sehingga kajian keilmuan PKn, program kurikuler PKn, dan aktivitas sosial-kultural PKn saat ini benar-benar bersifat multifaset/multidimensional. Sifat multidimensional ini yang membuat bidang studi PKn dapat disikapi sebagai: pendidikan kewarganegaraan, pendidikan politik, pendidikan nilai dan moral, pendidikan kebangsaan, pendidikan kemasyarakatan, pendidikan hukum dan Hak azasi Manusia dan pendidikan demokrasi (Winataputra, 2012, hal. 14).

Aspek epistemologi pendidikan kewarganegaraan berkaitan erat dengan aspek ontologi pendidikan kewarganegaraan, karena memang proses epistemologis, yang pada dasarnya berwujud dalam berbagai bentuk kegiatan sistematis dalam upaya membangun pengetahuan bidang kajian ilmiah pendidikan kewarganegaraan sudah seharusnya terkait pada obyek telaah dan obyek pengembangannya.

Dalam aspek epistemologis, pendidikan kewarganegaraan sebagai bidang kajian ilmiah berkaitan erat dengan aspek-aspek epistemologi pendidikan disiplin ilmu pengetahuan sosial. Karena bidang kajian ilmiah pendidikan kewarganegaraan dan pendidikan ilmu sosial merupakan dua kajian yang dilandasi oleh dua pemikiran yang sama yaitu (1) unsur "interaceptive knowledge" yang diturunkan dari tujuan negara dan fungsi tujuan nasional. (2) unsur "exterceptive knowledge" yang digali dari struktur disiplin ilmu-ilmu sosial, dan dikontekstualisasikan dalam berkehidupan bermasyarakat, berbangsa, dan bernegara (Somantri \& Winataputra, 2017, hal. 53-54).

Secara aksiologis pendidikan kewarganegaraan yang sekarang ada di Indonesia memfokuskan pada pembentukan warga negara yang memahami dan mampu melaksanakan hak-hak dan kewajibannya untuk menjadi warga negara Indonesia yang cerdas, terampil, dan berkarakter yang diamanatkan oleh Pancasila dan UUD 1945. Pendidikan Kewarganegaraan tersebut di tumbuh kembangkan dalam tradisi Citizenship Education yang tujuannya sesuai dengan tujuan nasional negara. Namun, secara umum menurut Nu'man Somantri dalam pendapatnya di atas tujuan mengembangkan pendidikan kewarganegaraan (PKn) adalah agar setiap warga negara menjadi warga negara yang baik (to be good citizens), yakni warga yang memiliki kecerdasan (Civic Intelligence) baik intelektual, emosional, sosial, maupun spiritual; memiliki rasa bangga dan tanggung jawab (Civic Responsibility); dan mampu berpartisipasi dalam kehidupan bermasyarakat dan bernegara (Civic Participation) agar tumbuh rasa kebangsaan dan cinta tanah air.

\section{Tinjauan Sosiologis}

Untuk memahami tentang bagaimana pendidikan kewarganegaraan di SMP secara sosiologis, maka di sini akan dijelaskan tentang teori perkembangan sosial peserta didik dari dua tokoh paling berpengaruh dalam pendidikan yakni Erikson dan Bronfenbranner. Terdapat beberapa teori tentang perkembangan sosioemosional anak. Untuk 
membahas tentang perkembangan sosial peserta didik, kita akan fokus pada dua teori; pertama teori ekologi dari Bronfenbrenner dan kedua teori perkembangan rentang hidup (life span) dari Erikson. Dua teori ini dipilih karena cukup komprehensif membahas tentang konteks sosial dimana anak berkembang dan perubahan utama perkembangan sosioemosional.

Teori ekologi dikembangkan oleh Urie Bronfenbranner seseorang ahli psikologi dari Cornell University Amerika Serikat, yang fukus utamanya adalah pada konteks sosial dimana anak tinggal dan orang-orang yang mempengaruhi perkembangan anak. Teori Ekologi Bronfanbranner meliputi lima sistem lingkungan yang merentang dari interaksi interpersonal sampai pengaruh kultur yang lebih luas. Lima sistem lingkungan tersebut adalah; mikrosistem, mesosistem, ekosistem, dan kronosistem (Santrock, 2008, hal. 84).

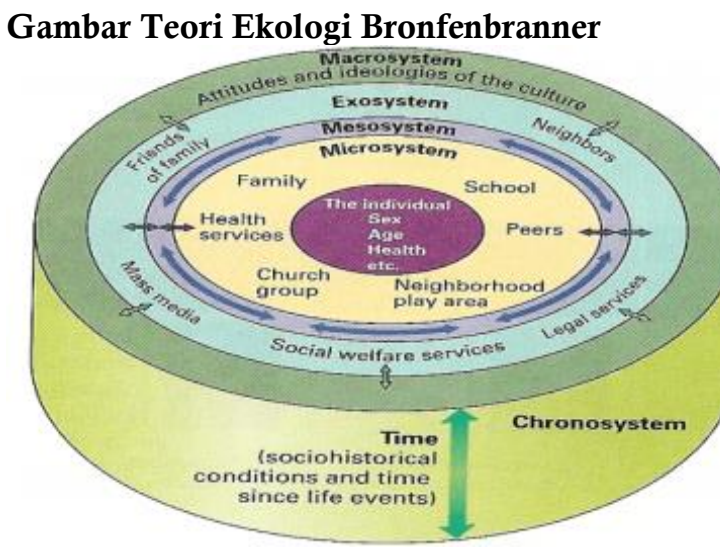

Pertama adalah mikrosistem, yaitu setting dimana individu menghabiskan banyak waktu. Dalam konteks ini antara lain keluarga, teman sebaya, sekolah dan tetangga. Dalam mikrosistem ini individu berinteraksi langsung dengan orang tua, guru, teman sebaya dan orang lain. Menurut Brofanbanner anak bukan penerima pengalaman secara pasif di dalam setting ini, tetapi anak adalah orang yang berinteraksi timbal balik dengan orang lain dan membantu mengkonstruksi setting tersebut. Kedua, mesositem yaitu kaitan antara mikrosistem. Contohnya adalah hubungan antara pengalaman dalam keluarga dengan pengalaman di sekolah dan antara keluarga dan teman sebaya. Misalnya, salah satu mesosistem penting adalah hubungan antara sekolah dan keluarga. Ketiga, ekosistem, terjadi ketika pengalaman di setting lain (dimana murid tidak berperan aktif) memengaruhi pengalaman murid dan guru dalam konteks mereka sendiri. Misalnya, ambil contoh dewan sekolah dan dewan pengawas taman di dalam suatu komunitas. Mereka memegangi peran kuat dalam menentukan kualitas sekolah, taman, fasilitas rekreasi, dan perpustakaan. Keputusan mereka bisa membantu atau menghambat perkembangan anak.
Keempat, makrosistem, adalah kultur yang lebih luas. Kultur adalah istilah luas yang mencakup peran etnis dan faktor sosioekonomi dalam perkembangan anak. Kultur adalah konteks terluas di mana murid dan guru tinggal, termasuk nilai dan adat istiadat masyarakat. Misalnya, beberapa kultur (seperti si negara Islam semacam Mesir atau Iran), menekankan pada peran gender tradisonal. Kultur lain (seperti di AS) menerima peran gender yang lebih bervariasi. Di kebanyakan negara Islam, sistem pendidikannya mempromosikan dominasi pria. Di Amerika, sekolah-sekolah semakin mendukung nilai kesetaraan antara pria dan wanita. Dan yang kelima kronosistem, yaitu kondisi sosiohistoris dari perkembangan anak. Misalnya, murid-murid sekarang ini tumbuh sebagai generasi yang tergolong pertama (Louv, 1990). Anak-anak sekarang adalah generasi pertama yang mendapatkan perhatian setiap hari, generasi pertama yang tumbuh di lingkungan elektronik yang dipenuhi oleh komputer dan bentuk media baru, generasi pertama yang tumbuh dalam revolusi seksual, dan generasi pertama yang tumbuh di dalam kota yang semrawut dan tak terpusat, yang tidak lagi jelas batas antara kota, pedesaan atau subkota (Santrock, 2008, hal. 84-85).

Bronferbrenner makin banyak memberi perhatian kepada kronosistem sebagai sistem lingkungan yang penting. Dia memerhatikan dua problem penting: (1) banyaknya anak di Amerika yang hidup dalam kemiskinan, terutama dalam keluarga single parent; dan (2) penurunan nilai-nilai.

Teori ekologi Bronferbrenner mendapat kritikan dari beberapa ahli, yang mengatakan bahwa teori Bronferbrenner tidak memberi perhatian pada faktor biologis dan kognitif dalam perkembangan anak. Teori Bronferbrenner juga dikritik karena tidak membahas perubahan perkembangan bertahap yang menjadi fokus dari teori-teori seperti teori Piaget dan Ericson.

Untuk itu teori ekologi Bronfenbranner disempurnakan oleh Erikson dengan teori perkembangan rentang hidup. Menurut Erikson (Santrock, 2008, hal. 86), terdapat delapan perkembangan manusia yang akan dilalui sepanjang rentang kehidupannya. Masing-masing tahap terdiri dari tugas perkembangan yang dihadapi oleh individu yang mengalami krisis. Menurut Erikson, masing-masing krisis tidak bersifat katastropik, tetapi merupakan titik balik ari kerawanan dan penguatan potensi. Semakin sukses seseorang mengatasi krisisnya, maka semakin sehat psikologi individu tersebut.

Delapan tahap perkembangan manusia menurut Erikson, secara singkat dapat digambarkan dalam tabel berikut ini. 
Tabel. 1

Tahap rentang hidup Ericson

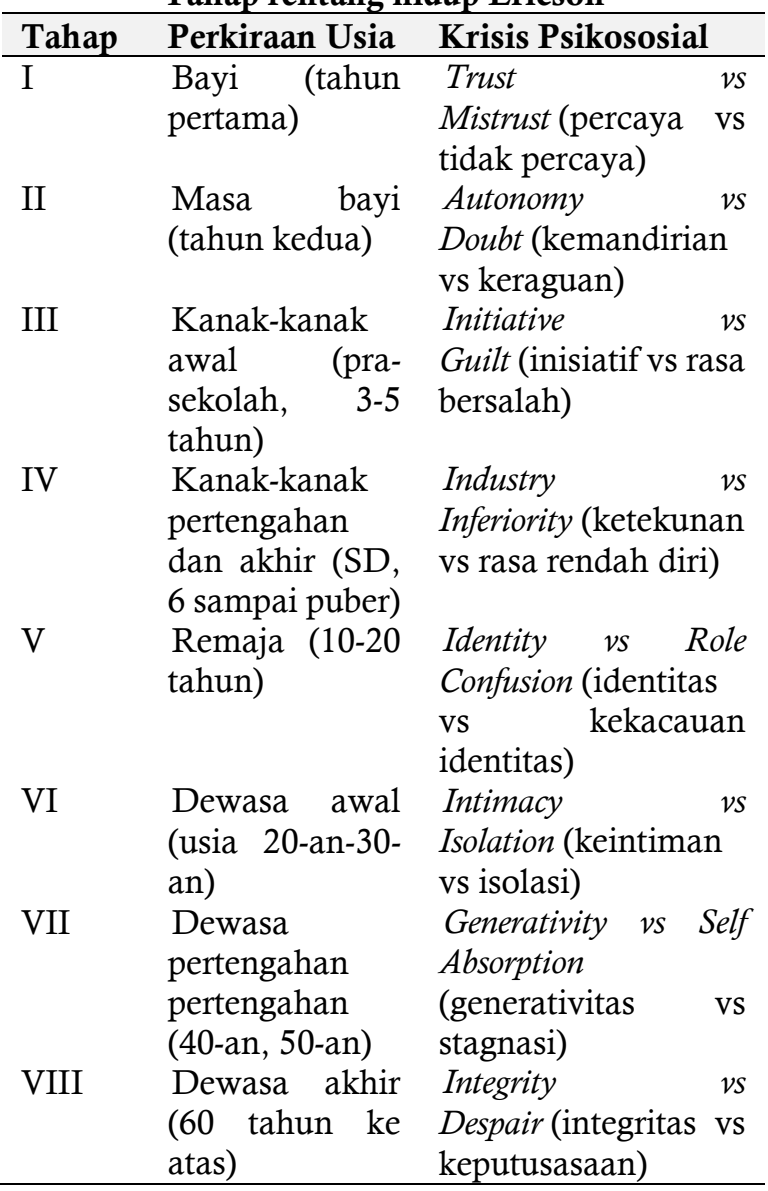

Diolah dari (Santrock, 2008, hal. 87) berikut:

Dari tabel diatas dapat dijelaskan sebagai

\section{Trust vs Mistrust (percaya vs tidak percaya)}

Perkembangan kepercayaan (trust) membutuhkan pengasuhan yang hangat dan bersahabat. Hasil positifnya adalah rasa nyaman dan berkurangnya ketakutan sampai pada titik minimal. Ketidakpercayaan akan tumbuh jika bayi diperlakukan terlalu negatif atau diabaikan.

\section{Autonomy vs Doubt (kemandirian vs keraguan)}

Tahap ini terjadi pada masa bayi akhir dan masa belajar berjalan. Setelah memercayai pengasuhnya, bayi mulai menemukan bahwa tindakannya adalah tindakannya sendiri. Mereka menegaskan independensinya dan menyadari kehendaknya sendiri. Jika bayi dibatasi terlalu banyak atau dihukum terlalu keras, mereka akan mengembangkan rasa malu dan ragu.

\section{Initiative vs Guilt (inisiatif vs rasa bersalah)}

Tahap ini berhubungan dengan masa kanak-kanak awal, sekitar umur tiga hingga lima tahun. Saat anak-anak merasakan dunia sosial yang lebih luas, mereka mendapat lebih banyak tantangan ketimbang saat masih bayi. Untuk mengatasi tantangan ini mereka harus aktif dan tindakannya mempunyai tujuan. Dalam tahap ini, orang dewasa berharap anak menjadi lebih bertanggungjawab dan menyuruh anak mengemban beberapa tanggungjawab untuk menjaga tubuh dan milik mereka. Memunculkan rasa bertanggungjawab membutuhkan inisiatif. Anak mengembangkan rasa bersalah apabila mereka tidak bertanggungjawab atau merasa terlalu cemas.

4. Industry vs Inferiority (ketekunan vs rasa rendah diri)

Tahap ini terjadi kira-kira pada masa sekolah dasar, dari usia enam tahun hingga usia puber atau remaja awal. Inisiatif anak membuat mereka berhubungan dengan banyak pengalaman baru. Saat mereka masuk sekolah dasar, mereka menggunakan energinya untuk menguasai pengetahuan dan keterampilan intelektual. Masa kanak-kanak akhir adalah masa paling bersemangat untuk belajar, saat imajinasi mereka berkembang. Bahaya di masa sekolah dasar ini adalah munculnya perasaan rendah diri, ketidakproduktivan, dan inkompetensi.

\section{Identity vs Role Confusion (identitas vs kekacauan identitas)}

Tahap ini terjadi di masa remaja. Remaja berusaha untuk mencari tahu jati dirinya, apa makna dirinya, dan kemana mereka menuju. Mereka berhadapan dengan banyak peran baru dan status dewasa (seperti pekerjaan dan pacaran). Remaja perlu diberi kesempata untuk mengeksplorasi berbagai cara untuk memahami identitas dirinya. Apabila remaja tidak cukup mengeksplorasi peran yang berbeda dan tidak merancang jalan ke masa depan yang positif mereka bisa tetap bingung akan identitas diri mereka.

\section{Intimacy vs Isolation (keintiman vs isolasi)}

Tahap ini terjadi pada masa dewasa awal tugas perkembangannya adalah membentuk hubungan yang positif dengan orang lain. Ericson mendeskripsikan intimasi sebagai penemuan diri sendiri tetapi kehilangan diri sendiri dalam diri orang lain. Bahaya pada tahap ini adalah orang bisa gagal membangun hubungan dekat dengan pacar atau kawannya dan terisolasi secara sosial. Bagi individu seperti ini kesepian bisa membayangi seluruh hidup mereka.

\section{Generativity vs Self Absorption (generativitas vs stagnasi)}

Tahap ini terjadi pada masa dewasa pertengahan, sekitar usia 40-an dan 50-an. Generativitas berarti mentransmisikan sesuatu positif kepada generasi selanjutnya. Ini bisa berkaitan dengan peran seperti 
parenting dan pengajaran. Melalui peran itu orang dewasa membantu generasi selanjutnya untuk mengembangkan hidup yang berguna. Erikson mendeskripsikan stagnasi sebagai perasaan tidak bisa melakukan apa-apa untuk membantu generasi selanjutnya.

\section{Integrity vs Despair (integritas vs keputusasaan)}

Tahap ini berhubungan dengan masa dewasa akhir, sekitar usia 60-an sampai meninggal. Orang tua merenungi kembali hidupnya, memikirkan apa-apa yang telah mereka lakukan. Jika evaluasi restrospektif ini positif, mereka akan mengembangkan rasa integritas. Yakni mereka memandang hidup mereka sebagai hidup yang utuh dan positif, dan layak dijalani. Sebaliknya, orang tua akan putus asa jika renungan mereka kebanyakan negatif (Santrock, 2008, hal. 87-88).

Jika dilihat secara keseluruhan, teori Ericson merupakan faktor penting dalam membentuk pandangan kita sekarang tentang perkembangan manusia sebagai perkembangan sepanjang hayat, bukan sekadar perkembangan di masa kanak-kanak. Masa anak usia SMP berkembang social cognition yaitu kemampuan untuk memahami orang lain. Remaja memahami orang lain sebagai individu yang unik, baik menyangkut sifat-sifat peribadi, minat nilai-nilai maupun perasaan. Pemahamannya ini, mendorong remaja untuk menjalin hubungan sosial yang lebih akrap dengan mereka (terutama teman sebaya), baik melalui jalinan persahabatan maupun percintan (pacaran). Dalam hubungan persahabatan, remaja memilih teman yang memiliki kualitas psikologis yang relatif sama dengan dirinya, baik menyangkut interes, sikap, nilai, dan kepribadian.

Jika dilihat dari teori perkembangan sosial Erikson ini anak usia SMP berada dalam tingkat 5, Identity vs Role Confusion, dimana remaja sedang dalam usaha sedang mencari jati dirinya. Anak-anak remaja perlu diberi kesempatan untuk mengeksplorasi berbagai cara untuk memahami identitas dirinya. Apabila remaja tidak cukup mengeksplorasi peran yang berbeda dan tidak merancang jalan ke masa depan yang positif mereka bisa tetap bingung akan identitas diri mereka. Untuk itu, materi pendidikan kewarganegaraan dan teknik pembelajaran PKn harus disesuaikan dengan perkembangan sosial remaja tersebut.

\section{Tinjauan Yuridis}

Pendidikan kewarganegaraan dalam konteks formal secara yuridis tidak tidak terlepas dari esensi yang terkandung dalam ideologi dan konsepsi utuh satu sistem pendidikan nasional sebagaimana termaktub dalam UUD 1945 pasa 31 ayat (3) yang berbunyi "pemerintah mengusahakan dan menyelenggarakan satu sistem pendidikan nasional yang meningkatkan keimanan, ketakwaan serta akhlak mulia dalam rangka mencerdaskan kehidupan bangsa, yang diatur dengan undangundang". Selanjutnya dalam ketentuan turuanannya UU No. 20 Tahun 2003 tentang Sistem Pendidikan Nasional pasal 2 dinyatakan bahwa "pendidikan nasional berdasarkan Pancasila dan UndangUndang Dasar Negara Republik Indonesia Tahun 1945".

Secara spesifik, pendidikan kewarganegaraan menjadi salah satu pelajaran yang wajib ada dalam setiap jenjang pendidikan menurut pasal 37 UU No. 20 Tahun 2003 tentang Sistem Pendidikan Nasional. Dalam penjelasannya disebutkan bahwa pendidikan kewarganegaraan dimaksudkan untuk membentuk peserta didik menjadi manusia yang memiliki rasa kebangsaan dan cinta tanah air. Ketentuan ini berlaku untuk semua jenjang pendidikan dari dasar, menengah, hingga pendidikan tinggi. Berdasarkan rumusan tersebut, telah dikembangkan Mata pelajaran Pendidikan Pancasila dan Kewarganegaraan (PPKn) yang diharapkan dapat menjadi wahana edukatif dalam mengembangkan peserta didik menjadi manusia yang memiliki rasa kebangsaan dan cinta tanah air yang dijiwai oleh nilai-nilai Pancasila, Undang Undang Dasar Negara Republik Indonesia Tahun 1945, semangat Bhinneka Tunggal Ika dan komitmen Negara Kesatuan Republik Indonesia.

Sebagai wahana pendidikan formal pada jenjang pendidikan dasar dan menengah, pendidikan kewarganegaraan secara kurikuler bertujuan mengembangkan potensi peserta didik dalam seluruh dimensi kewarganegaraan, yakni; (1) pengetahuan kewarganegaraan, (2) sikap kewarganegaraan, (3) keterampilan kewarganegaraan, (4) keteguhan kewarganegaraan, (5) komitmen kewarganegaraan, (6) kompetensi kewarganegaraan (Somantri \& Winataputra, 2017, hal. 94). Semua ranah tujuan itu harus didudukkan dalam konteks ideologisasi, instrumentasi dan aktualisasi Pancasila sebagai dasar negara, ideologi nasional, dan pandangan hidup bangsa. Oleh karena itu Pancasila harus dikonsepsikan, dimaknai, dan difungsikan sebagai entitas inti, sumber rujukan dan kriteria keberhasilan proses belajar dan pembelajaran.

Menurut Permendikbud No. 58 Tahun 2014, secara umum tujuan mata pelajaran Pendidikan Pancasila dan Kewarganegaraan pada jenjang pendidikan dasar dan menengah adalah mengembangkan potensi peserta didik dalam seluruh dimensi kewarganegaraan, yakni: (1) sikap kewarganegaraan termasuk keteguhan, komitmen, dan tanggungjawab kewarganegaraan (civic confidence, civic committment, and civic responsibility); (2) pengetahuan kewarganegaraan; (3) keterampilan 
kewarganegaraan termasuk kecakapan dan partisipasi kewarganegaraan (civic competence and civic responsibility).

Dalam Permendikbud No. 58 tahun 2014 juga disebutkan mengenai tujuan PPKn yang berisikan keseluruhan dimensi tersebut, sehingga peserta didik mampu: (1) menampilkan karakter yang mencerminkan penghayatan, pemahaman, dan pengamalan nilai dan moral Pancasila secara personal dan sosial; (2) memiliki komitmen konstitusional yang ditopang oleh sikap positif dan pemahaman utuh tentang Undang-undang Dasar Negara Republik Indonesia Tahun 1945; (3) berpikir secara kritis, rasional dan kreatif, serta memiliki semangat kebangsaan serta cinta tanah air yang dijiwai oleh nilai-nilai Pancasila, Undang-undang Dasar Negara Republik Indonesia Tahun 1945, semangat Bhinneka Tunggal Ika, dan komitmen Negara Kesatuan Republik Indonesia; (4) berpartisipasi secara aktif sebagai anggota masyarakat, tunas bangsa, dan warga negara sesuai dengan harkat dan martabatnya sebagai mahluk ciptaan Tuhan Yang Maha Esa yang hidup bersama dalam berbagai tatanan sosial budaya.

Dalam kurikulum 2013, mata pelajaran pendidikan kewarganegaraan menjadi Pendidikan Pancasila dan Kewarganegaraan (PPKn). Sebagaimana dijelaskan dalam Permendikbud N0. 58 Tahun 2014, ruang lingkup PPKn meliputi: (1) Pancasila sebagai dasar negara, ideologi, dan pandangan hidup bangsa; (2) UUD 1945 sebagai hukum dasar tertulis yang menjadi landasan konstitusional kehidupan bermasyarakat, bernbangsa, dan bernegara;(3) Negara Kesatuan Republik Indonesia, sebagai kesepakatan final bentuk Negara Republik Indonesia, dan (4) Bhinneka Tunggal Ika sebagai wujud filosofi kesatuan yang melandasi dan mewarnai keberagaman kehidupan bermasyarakat, bebangsa, dan bernegara.

Dengan demikian PPKn lebih memiliki kedudukan dan fungsi sebagai berikut: (1) PPKn merupakan pendidikan nilai, moral/karakter, dan kewarganegaraan khas Indonesia yang tidak sama sebangun dengan civic education di USA, citizenship education di UK, talimatul muwatanah di negaranegara Timur Tengah, education civicas di Amerika Latin; (2) PPKn sebagai wahana pendidikan nilai, moral/karakter Pancasila dan pengembangan kapasitas psikososial kewarganegaraan Indonesia sangat koheren (runut dan terpadu) dengan komitmen pengembangan watak dan peradaban bangsa yang bermartabat dan perwujudan warga negara yang demokratis dan bertanggung jawab sebagaimana termaktub dalam Pasal 3 UU No.20 Tahun 2003.

\section{Tinjauan Psikologis}

Dalam Permendikbud No. 58 tahun 2014 disebutkan salah satu tujuan PPKn adalah agar peserta didik mampu menampilkan karakter yang mencerminkan penghayatan, pemahaman, dan pengamalan nilai dan moral Pancasila secara personal dan sosial. Menurut Somantri dan Winataputra (2017, hal. 73) proses penghayatan mengandung arti "proses batin". Untuk tercapainya proses batin berkenaan dengan pengertian tentang nilai-nilai Pancasila itu disaratkan agar ada pengenalan dan pengertian tentang nilai-nilai itu. Dari sini diharapkan terciptanya kesadaran diri sehingga individu dapat mengamalkannya. Konsepsi PPKn sebagai pendidikan karakter/pendidikan moral perlu dipahami dari beberapa penelitian tentang perkembangan moral dan pendidikan moral, di antaranya adalah oleh Jean Piaget dan Lawrence Kohlberg.

Menurut kedua tokoh tersebut, proses tumbuh dan berkembangnya peserta didik akan selalu berkorelasi dengan berkembangnya kognitif pada diri anak. Semakin tinggi umur anak, maka semakin kompleks susunan sel sarafnya dan semakin meningkatkan kemampuan anak dalam menyerap pengetahuan yang bisa diperoleh peserta didik. Sebagaimana disampaikan oleh Jean Piaget (Budiningsih, 2005, hal. 35) Untuk itu, bagi pendidik penting untuk mengetahui Membicarakan perkembangan peserta didik akan selalu mengaitkannya dengan perkembangan kognitif. Hal ini penting untuk diketahui oleh pendidik khususnya yang berkecimpung langsung dalam proses kegiatan belajar-mengajar agar proses pembelajaran yang dilakukan penuh dengan kebermaknaan. Pembelajaran yang tidak disesuaikan dengan perkembangan kognitif peserta didik tentu tidak akan menghasilkan hasil yang baik. Menurut Santrock (2001:40) para psikolog membicarakan perkembangan anak adalah pola perubahan biologis, kognitif, dan sosioemosional yang dimulai sejak lahir dan akan terus berlanjut sepanjang hayat manusia. Proses pendidikan harus sesuai dengan perkembangan kognitif dari peserta didik, artinya pengajaran yang dilakukan harus dilakukan pada tingkat kemampuan kognitif anak.

\section{Teori Perkembangan Kognitif Peserta Didik}

Perkembangan kognitif peserta didik berkembang dipengaruhi oleh potensi yang ada dalam dirinya serta dikembangkan oleh pengalaman yang diperoleh dari lingkungan di mana peserta didik berada. Tugas dari pendidik adalah menyediakan lingkungan yang memungkinkan peserta didik agar memperoleh pengalaman yang mampu mengembangkan potensi diri peserta didik secara wajar. 
Menurut Piaget (Santrock, 2014, hal. 93) proses belajar akan terjadi jika mengikuti tahap - tahap asimilasi, akomodasi, dan ekuilibrasi (penyeimbangan). Proses asimilasi merupakan proses pengintegrasian atau penyatuan informasi baru kedalam struktur kognitif yang telah dimiliki oleh individu. Proses akomodasi merupakan proses penyesuaian struktur kognitif kedalam situasi yang baru. Sedangkan proses ekuilibrasi adalah penyesuaian berkesinambungan antara asimilasi dan akomodasi. Artinya, individu tersebut sudah dapat mengaplikasikan atau memakai prinsip prinsip dalam situasi yang baru dan spesifik. Menurut Piaget proses belajar seseorang akan mengikuti pola dan tahap - tahap perkembangan sesuai dengan umurnya. Pola dan tahap-tahap ini bersifat hierarkis (tahap sensorimotor, preoperasional, oprasional kongkrit, dan operasional formal), artinya harus dilalui berdasarkan urutan tertentu dan seseorang tidak dapat belajar sesuatu yang berada diluar tahap kognitifnya.

Jean Piaget telah melakukan banyak kajian dan eksperimen dalam bidang psikologi pembelajaran. Piaget berpendapat bahwa pemikiran anak-anak berbeda pada masing-masing tingkatan. Maka dari itu ia membagi perkembangan kognitif dalam empat tingkatan; 1). Tingkat sensori motor pada umur 0-2 tahun, 2). Tingkat praoperasi pada umur 2-7 tahun, 3). Tingkat operasi konkret pada umur 7-11 tahun, dan 4). Operasi formal pada umur 11 tahun ke atas.

\section{1) Tahap sensori motor}

Tahap sensori motor merupakan tahap pertama dalam teori Piaget yang memiliki rentang umur 0 sampai 2 tahun. Pada tahap ini anak yang masih dikatakan sebagai bayi, membangun suatu pengalaman tentang dunia dengan mengkoordinasikan pengalaman-pengalaman sensoris, seperti melihat dan mendengar, dengan tindakan motorik-fisik. Oleh karena itu istilah pada tingkatan ini dinamakan sebagai sensorimotor (Santrock, 2014, hal. 94). Seorang anak yang masih bayi ini belajar tentang diri mereka sendiri dan dunia di luar dirinya melalui indera mereka yang sedang berkembang dan melalui aktifitas motorik yang diamati atau dirasakan oleh alat inderanya. Selanjutnya sedikit demi sedikit individu mengembangkan kemampuannya untuk membedakan dirinya dengan benda-benda lain. Proses ini merupakan dasar bagi perkembangan kognitif selanjutnya, aktifitas sensori motor terbentuk melalui proses penyesuaian sruktur fisik sebagai hasil dari interaksi dengan lingkungan (Surya, 2003, hal. 57). Pada permulaan tahap ini, bayi yang baru lahir sedikit lebih banyak daripada pola-pola refleks. Pada akhir tahap usia 2 tahun memiliki pola sesnori motor yang kompleks dan mulai beroperasi dengan simbol-simbol primitif.

\section{2) Tahap praoperasi}

Pada tahap praoperasi, rentang usia anak antara 2 sampai 7 tahun. Pada tahap ini, anak-anak mulai melukiskan dunia dengan kata-kata dan gambar (Santrock, 2014, hal. 94). Pada tingkat ini anak-anak lebih sosial dan menggunakan bahasa serta tanda untuk menggambarkan suatu konsep. Secara jelas penggunaan bahasa pada masa ini menggunakan cara berfikir simbolik dan intuitif (Suparno, 2001, hal. 49). Pemikiran simbolis yaitu pemikiran dengan menggunakan simbol atau tanda, berkembang sewaktu anak mulai suka menirukan sesuatu. Keaktifan anak menirukan orang tuanya akan memperlancar pemikiran simbolisnya. Demikian juga kemampuan sorang anak menirukan berbagai hal yang dialami dalam hidupnya akan membantu pembentukan simbolisnya. Dengan adanya penggunaan simbol, anak dapat mengungkapkan suatu hak yang terjadi serta dapat membicarakan macam-macam benda dalam waktu bersamaan. Pemikiran intuitif adalah persepsi langsung akan dunia luar tetapi tanpa dinalar terlebih dahulu (Suparno, 2001, hal. 62). Intuisi merupakan pemikiran imajinal atau sensasi langsung tanpa dipikir terlebih dahulu. Artinya, pada tahap praoperasi ini individu mulai melukiskan dunia dengan tingkah laku, dan kata-kata. Tapi belum mampu untuk melakukan operasi, yaitu melakukan tindakan mental yang diinternalisasikan. Individu memiliki kecakapan motorik untuk melakukan sesuatu dari apa yang dilihat dan di dengar tetapi belum mampu memahami secara hakikat terhadap apa yang dilakukannya tersebut.

\section{3) Tahap operasi konkret}

Rentang usia pada tahap ini adalah pada 7-11 tahun. Anak-anak pada usia ini dapat melakukan operasi dan penalaran logis menggantikan pemikiran intuitif sejauh pemikiran dapat diterapkan ke dalam contoh-contoh yang spesifik atau konkret (Santrock, 2014, hal. 94). Operasi itu bersifat reversibel, artinya dapat mengerti dalam dua arah, yaitu suatu pemikiran yang dapat dikembalikan kepada awalnya lagi. Yang juga sangat maju dalam tahap ini adalah kemampuan anak mengurutkan dan mengklasifikasi objek.

Dengan operasi itu anak telah mengembangkan pemikiran logis yang dapat diterapkan dalam memecahkan masalah-masalah konkret yang dihadapi. Akan tetapi, dalam tahapan operasional konkret ini memiliki beberapa kelemahan, yaitu meskipun sudah mampu mengembangkan pemikiran logis, tetapi masih terbatas pada suatu yang konkret, belum bersifat abstrak apalagi hipotesis. Dengan kata lain, bila 
anak dihadapkan dengan masalah secara verbal dan tidak konkret maka anak belum mampu menyelesaikan masalah tersebut dengan baik.

\section{4) Tahap operasi formal}

Pada tahap operasi formal terjadi pada anak dengan rentang umur 11 tahun ke atas. Anak pada tahap ini telah melampaui dunia nyata, pengalamanpengalaman konkret dan berpikir secara abstrak dan lebih logis (Santrock, 2014, hal. 95). Mereka menyelesaikan permasalahan yang dihadapi dengan reasoning dan logika. Ada pembebasan pemikiran dan pengalaman langsung menuju ke pemikiran yang berdasarkan proposisi dan hipotesis. Asimilasi dan hipotesi terus berperan dalam membentuk skema yang lebih menyeluruh pada pemikiran remaja. Pada saat ini, pemikiran remaja dengan pemikiran orang dewasa sama secara kualitas, namun berbeda secara kuantitas (Suparno, 2001, hal. 100). Artinya, pada tahap operasi formal Individu dapat berpikir secara abstrak, lebih logis dan idealis.

Pada pemikiran formal, unsur pokok pemikiran adalah pemikiran deduktif, induktif, dan abstraktif. Pemikiran deduktif mengambil kesimpulan khusus dari pengalaman umum. Pemikiran induktif, mengambil kesimpulan umum dari pengalaman khusus. Pemikiran abstraktif tidak langsung dari objek. Pada tahap perkembangan ini, remaja sudah dapat memahami konsep preposisi dengan baik, menggunakan kombinasi dalam pemikirannya, dapat menggabungkan dua referensi pemikiran, sudah mengerti probabilitas dengan unsur yang menyertainya serta permutasinya.

Berdasarkan penjelasan tersebut maka masamasa usia remaja awal pada anak di jenjang SMP sudah mencapai tahap operasi formal. Pada usia ini secara mental anak telah dapat berpkir logis tentang berbagai gagasan yang abstrak. Dengan kata lain, berpikir operasi formal lebih bersifat hipotesis dan abstrak serta sistematis dan ilmiah dalam memecahkan masalah daripada berpikir konkrit.

Jadi implikasi pendidikan dalam tahap ini atau tahap operasi formal adalah perlunya disiapkan program pendidikan atau bimbingan yang memfasilitasi perkembangan kemampuan berpikir siswa. Upaya yang dapat dilakukan antara lain (1) penggunaan metode mengajar yang mendorong anak untuk aktif bertanya, megemukakan gagasan, atau mengujicobakan suatu materi, dan (2) melakukan dialog, diskusi, atau curah pendapat dengan siswa tentang masalah-masalah sosial, baik itu menyangkut sosiologi, geografi, ekonomi, maupun sejarah.

\section{Teori perkembangan Moral dan Nilai Peserta Didik}

Perkembangan moral melibatkan perubahan dalam pikiran, perasaan, dan perilaku mengenai standar benar dan salah. Pengembangan moral memiliki dimensi intrapersonal, yang mengatur aktivitas seseorang ketika dia tidak terlibat dalam interaksi sosial, dan dimensi interpersonal, yang mengatur interaksi sosial dan menengahi konflik (Santrock, 2014, hal. 229-230).

Menurut Santrock (2014, hal. 230) Untuk memahami perkembangan moral, kita perlu mempertimbangkan lima pertanyaan dasar; Pertama, bagaimana remaja beralasan, atau berpikir, tentang aturan untuk perilaku yang beretika?. Kedua, bagaimana sebenarnya remaja berperilaku dalam keadaan moral? Ketiga, bagaimana perasaan remaja tentang masalah moral? Keempat, apa meliputi kepribadian moral remaja? Kelima, bagaimana domain moral remaja berbeda dari domain sosial dan pribadi remaja? Perlu diingat bahwa meskipun Santrock telah memisahkan perkembangan moral ke dalam domain yang berbeda, komponen-komponen yang ada didalamnya sering saling terkait. Misalnya, jika fokusnya adalah pada perilaku remaja, penting untuk mengevaluasi niat remaja (moral thought). Demikian pula, emosi yang menyertai, dan dapat mendistorsi, penalaran moral.

Teori Jean Piaget tentang perkembangan kognitif peserta didik juga mencakup tentang perkembangan penalaran moral. Secara intensif Piaget telah melakukan penelitian dasar tentang moral selama lebih dari 40 tahun terhadap perkembangan kognitif (cognitive structure) dan perkembangan moral (moral judgement). Mengenai kemampuan kognisi, piaget berpendapat bahwa perkembangan moral berlangsung dalam tahaptahap yang dapat diprediksi, dalam hal ini dari tipe penalaran moral yang sangat egosentris ke tipe penalaran moral yang didasarkan pada sisitem keadilan berasarkan kerjasama dan tindakan timbal balik (Slavin, 2011, hal. 68). Dalam hasil penelitiannya, Piaget menyimpulkan bahwa anakanak berpikir dengan dua cara berbeda tentang moralitas, dan sangat bergantung dengan kematangan perkembangan mereka yaitu: moralitas heteronom dan moralitas otonom (Santrock, 2003, hal. 439).

Indikator moralitas dideteksi dan diamati melalui suasana pemahaman dan pelaksanaan anak terhadap aturan permainan kelereng (the game of marble). Dalam pengamatannya, Piaget menemukan beberapa orientasi terhadap aturan permainan kelereng dilihat dari kesadarannya terhadap peraturan dan cara melakukan peraturan itu. Pada anak usia 2 tahun ke bawah tidak ada aturan yang membimbing kegiatan anak, tindakan hanya 
merupakan kegiatan motorik tanpa tujuan pikiran. Kemudian, pada usia 2-6 tahun mulai timbul secara berangsur-angsur kesadaran akan aturan. Pada usia 7-10 tahun anak mulai bergerak naik dari kesenangan psikomotorik (psycomotor pleasure) menuju pada tingkat kesadaran adanya perangkat atuan yang disepakati (Somantri \& Winataputra, 2017, hal. 76).

Anak termuda dalam kelompok usia ini masih dipengaruhi oleh kepatuhan heteronomous (heteronomous obedience) keputusan moral yang muncul dari interaksi yang tidak seimbang antara anak dan orang dewasa, selama masa pra sekolah hingga awal tahun pertama sekolah, anak terbenam dalam lingkungan otoriter dimana mereka menempati posisi inferior dari orang dewasa. Anak membangun kepatuhan moral yang absolut, tidak dapat berubah, dan kaku. Namun aturan sudah dikenal sebagai hal yang penting dalam tingkah laku sosial. Pada tahap ini anak memandang aturan moral sebagai suatu yang telah ditetapkan dari luar individu karena adanya figur otoritas. Menilai perilaku itu baik atau benar dengan mempertimbangkan hanya akibat yang ditimbulkan perilaku, tidak mempertimbangkan niat dari si pelaku. Sebagai contoh; memecahkan 1 buah gelas dengan sengaja dan memecahkan satu lusin gelas dengan tidak sengaja, maka yang baik adalah memecahkan gelas 1 buah yang sengaja, karena akibat yang ditimbulkan lebih kecil daripada memecahkan satu lusin gelas. Padahal memecahkan denngan sengaja memiliki unsur niat dari si pelaku, sedangkan ketidak sengajaan adalah bukan sebuah pelanggaran yang berarti.

Pada akhirnya anak berkembang menuju tahap autonomi seirama dengan berkembangnya kematangan kognitif (cognitive maturity). Pada usia 11-12 tahun anak berkembang menuju pada kemampuan berpikir abstrak (abstract reasoning) dimana mulai dirasakan pentingnya perhimpunan aturan (codification of rules). Kemampuan ini muncul dari status yang seimbang dalam hubungan di teman sebaya yang memperoleh pengertian tentang keadilan, perhatian terhadap hak-hak orang lain, persamaan hak, dan hubungan manusia. Dalam memberikan penilaian baik atau benarnya perilaku seseorang anak akan mempertimbangkan niat atau tujuan si pelaku. Moralitas autonomi digambarkan sebagai moralitas atas dasar persamaan dan demokrasi yang oleh Piaget dinamakan moralitas kerjasama.

Ada empat dimensi yang membedakan antara tahap moralitas heteronomi dan autonomi. Dimensi-dimensi ini didefinisikan berkenaan dengan ketidakmatangan atau tahap heteronomi yaitu 1) moral absolut. Anak berasumsi di semua waktu dan tempat peraturan yang berlaku sama.
Mereka memandang peraturan sebagai eksistensi dari diri mereka sendiri. 2) konsep tentang peraturan tidak dapat diubah. Anak meyakini bahwa peraturan adalah kaku dan tidak dapat diubah. 3) Keyakinan bahwa keadilan pasti ada. Anak berasumsi kemalangan yang terjadi pada dirinya diakibatkan kesalahan yang dilakukannya. Misalnya anak mencuri sesuatu tetapi gagal dan jatuh terluka maka dia berpikir hal itu terjadi akibat dia mencuri dan, terakhir mengevaluasi tanggung jawab yang berhubungan dengan sebab akibat. Anak menilai sebuah tindakan lebih didasarkan pada hasilnya daripada maksud pelaku (Ibda, 2011, hal. 383).

Selanjutnya, berkenaan dengan pentahapan perkembangan moral dari Jean Piaget, menurut Duska \& Whellen (1977:13-14) sebagaimana disampaikan oleh Numan Somantri dan Udin S. Winataputra (2017, hal. 76) beberapa hal perlu dicatat, yaitu;

1. Titik heteronomi dan autonomi lebih mengembangkan proses perkembangan daripada totalitas orientasi mental individu.

2. Dengan memulai pergaulan dan kerjasama, anak mengembangkan pengertiannya tentang tujuan, dan sumber aturan-aturan.

3. Anak sampai usia tujuh atau delapan tahun menempatkan dirinya dikendalikan oleh seluruh aturan.

4. Dalam menghargai aturan yang diterima dari luar, anak belum memiliki pengertian dan motovasi untuk berbuat ajeg (consistent) dengan aturan itu.

5. Baru pada tahap autonomi anak menyadari akan aturan dan menghubungkan dengan pelaksanaanya.

6. Tujuan dan arah perkembangan kesadaran akan aturan adalah pengertian yang autonomi, dan merupakan pelaksanaan dari aturan itu.

Dapat disimpulkan dari teori perkembangan moral Piaget ini adalah anak hidup dalam masyarakat dan juga berkembang secara intelektual, maka terdapat adanya hubungan antara perkembangan pengetahuannya mengenai aturan dan pengertian mengenai aturan itu. Berkenaan dengan hal tersebut, atas dasar bahwa individu satu dengan individu lainnya adalah berbeda, demikian pula konteks sosial masyarakat dimana individu terlibat di dalamnya (Somantri \& Winataputra, 2017, hal. 77).

Dengan menggunakan pendekatan-pendekatan kognitif seperti halnya yang dilakukan oleh Piaget, Lawrence Kohlberg mengembangkan sendiri teori tentang perkembangan penalaran moral. Dalam studi tentang perkembangan moral ini Kohlberg 
memilih untuk mempelajari alasan-alasan yang mendasari respon-respon moral. Menurut Kohlberg (Santrock, 2003, hal. 441) konsep yang paling penting dalam memahami perkembangan moral adalah internalisasi perubahan perkembangan dari tingkah laku yang dikontrol secara eksternal menjadi tingkah laku yang dikontrol oleh standar dan prinsip internal. Seiring dengan perkembangan anak dan remaja, pemikiran moral mereka menjadi lebih teriinternalisasi.

Dalam melakukan penelitiannya, Lawrence Kohlberg menggunakan teknik interviu setiap tiga tahun selama 18 tahun penelitian dalam mengembangkan teori tentang perkembangan moral. Sampel yang digunakan adalah 50 orang lakilaki Amerika dengan rentang usia 10-18 tahun. Sama halnya dengan Piaget, Kohlberg tidak memusatkan perhatian pada perilaku moral (moral behavior) dengan mempertimbangkan bahwa studying behavior does not tell much about moral maturity. Yang menjadi pusat perhatiannya ialah jawaban terhadap pertanyaan megapa (the reason given why) tentang suatu perbuatan yang baik atau yang buruk (Somantri \& Winataputra, 2017, hal. 77).

Untuk menggali informasi tentang alasan pembenar suatu tindakan atau tidak bertindak, Kohlberg mengembangkan kriteria yang melukiskan atau mengandung dilema moral terhadap para responden yang diinterviu untuk memberikan tanggapannya. Dari hasil studinya telah diidentifikasi enam tahap dalam tiga tingkatan perkembangan moral. Pentahapan ini dikenal dengan teori perkembangan moral Kohlberg.

1. Preconventional Reasoning (Penalaran prakonvensional)

Tingkat pra konvensional adalah tingkat paling bawah dari teori perkembangan moral Kohlberg. Dalam tingkat ini terdapat dua tahapan yaitu orientasi hukuman dan kepatuhan (punishment and obedience orientation) dan individualisme, tujuan instrumental, dan pertukaran (individualism, instrumental purpose, and exchange).

Tahap 1. Adalah orientasi hukuman dan kepatuhan (punishment and obedience orientation). Pada tahap ini pemikiran moral anak terkait dengan hukuman, anak memahami moralitas lebih karenena kepatuhannya terhadap hukuman. Misalnya anak-anak dan remaja mau mematuhi orang dewasa karena orang dewasa menyuruh mereka untuk patuh. Artinya, yang menentukan baik dan buruk suatu tindakan adalah konsekuensi fisik, dan bukan nilai atau arti dari konsekuensi ini.

Tahap 2. Adalah individualisme, tujuan instrumental, dan pertukaran (individualism, instrumental purpose, and exchange). Pada tahap ini individu mengejar kepentingan mereka sendiri tetapi juga membiarkan orang lain melakukan hal yang sama. Jadi, apa yang benar melibatkan pertukaran yang setara. Jadi tindakan dikatakan baik apabila secara instrumental memberikan kepuasan diri sendiri dan sewaktu-waktu memenuhi kebutuhan orang lain. Disini mulai tampak unsur keterbukaan dan pembalasan serta kepentingan bersama namun lebih banyak dilihat dari cara-cara fisik yang bersifat pragmatik. Tahapan ini digambarkan sebagai mencerminkan sikap "apa untungnya bagi saya?"

\section{Conventional Reasoning (Penalaran Konvensional)}

Penalarann konvensional adalah tingkat dua, atau tingkat menengah dalam teori perkembangan moral Kohlberg. Dalam tingkat ini individu mematuhi standar tertentu (internal), tetapi juga standar orang lain (eksternal) seperti orang tua atau hukum masyarakat. Dalam penalaran konvensional individu mengembangkan harapan tentang peran sosial. Artinya, pada tingkatan ini individu menilai keluarga, kelompok, bangsa sebagai sesuatu yang bernilai tanpa melihat apakah ada konsekuensi langsung dan nyata, tidak hanya konformitas, tetapi juga loyalitas. Tingkat penalaran konvensional terbagi menjadi dua yaitu; harapan interpersonal mutual, hubungan dan konformitas interpersonal (mutual interpersonal expectations, relationships and interpersonal conformity), dan moralitas sistem sosial (social systems morality).

Tahap 3. Adalah harapan interpersonal mutual, hubungan dan konformitas interpersonal (mutual interpersonal expectations, relationships and interpersonal conformity). Pada tahap ini individu menghagai kepercayaan, perhatian, dan kesetiaan pada orang lain sebagai dasar penilaian moral. Pada tahapan ini anak-anak mengadopsi standar moral orang tua mereka serta mencari tahu apa yang dipikirkan pleh orang tua mereka sebagai "gadis baik" atau "anak baik". Pada tahap ini suatu tindakan dikatakan baik apabila perbuatan itu menyenangkan atau dapat membantu orang lain dan disetujui oleh orang lain.

Tahap 4. Adalah moralitas sistem sosial (social systems morality). Pada tahap ini penilaian moral didasarkan pada pemahaman tatanan sosial, hukum, keadilan, dan tugas. Misal, remaja mungkin mengatakan bahwa, agarkomunitas dapat bekerja secara efektif mereka perlu dilindungi oleh undangundang yang dipatuhi oleh anggotanya. Dengan demikian, dalam penalaran tahap 4 ini individu terlibat dalam pengambilan perspektif sosial yang mencakup pentingnya menjadi warga negara yang baik. Artinya dalam diri individu sudah tampak adanya orientasi pada pemeliharaan ketertiban sosial. Perilaku yang baik adalah perilaku yang menunjukkan pelaksanaan kewajiban seseorang, 
penghargaan terhadap otoritas, dan pemeliharaan ketertiban sosial.

\section{Postconventional Reasoning (Penalaran pasca konvensional)}

Tingkatan ini adalah tingkat paling tinggi dalam teori perkembangan moral Kohlberg. Pada tingkat ini moralitas lebih bersifat internal. Individu mengakui nilai-nilai moral alternatif, mengeksplorasi opsi, kemudian memutuskan pada kode moral tertentu. Dalam penalaran pascakonvensional, individu terlibat dalam pemeriksaan yang disengaja atas alasan mereka untuk memastikan bahwa ia telah memenuhi standar etika yang tinggi. Pada tingkat ini telah tampak usaha yang jelas untuk menentapkan nilai-nilai dan prinsip-prinsip moral yang memiliki kesahihan (validity) dan merupakan penerapan yang merupakan bagian dari otoritas kelompok atau yang memegang otoritas yang merupakan bagian dari perilaku individu dalam kelompoknya. Tingkat penalaran pasca-konvensional terdiri dari dua tahap yaitu: kontrak sosial atau utilitas (social contract or utility and individual rights) dan hak individu, dan prinsip etika universal (universal ethical principle).

Tahap 5. Adalah kontrak sosial atau utilitas (social contract or utility and individual rights). Pada tahap ini, nilai memiliki alasan individual, hak, dan sebagai dasar prinsip atau melampaui hukum. Seseorang melampaui validitas hukum yang sebenarnya dana memeriksa sistem sosial sejauh mana mereka melindungi hak asasi manusia dan nilai-nilai dasar. Pada tahap ini tindakan yang dianggap baik dan benar cenderung untuk dilihat dari hak-hak umum individu dan dalam arti standar.

Tahap 6. Adalah hak individu, dan prinsip etika universal (universal ethical principle). Pernyataan penegasan. Tahap 6 ini adalah tahapan paling tinggi dalam teori perkembangan moral Kohlberg. Pada tahap ini seseorang telah mengembangkan standar moral berdasarkan hak asasi manusia secara universal. Seseorang pada tahapan ini ketika dihadapkan pada konflik antara hukum dan hati nurani, orang tersebut akan mengikuti hati nuraninya, meskipun keputusan tersebut beresiko bagi dirinya. Dalam tahapan ini kebaikan didefinisikan atas dasar keputusan hati nurani dari hak-hak umum individu yang telah diuji dan disepakati oleh seluruh masyarakat.

Keenam tahap di atas menghadirkan suatu pola pemikiran yang menyatu pada setiap pengalaman seseorang dan pandangannya atas hal-hal yang khusus tentang moral. Sekali pun setiap orang boleh menjadi mampu mengingat kaidah umum (civic virtues) tertentu, tidak setiap orang akan berpikir tentang isu-isu umum (civic issue) yang penting dengan cara yang sama atau bertindak sesuai kaidah yang telah sama "dipelajari". Oleh karena itu, tidak hanya mengajar ketentuan moral yang berhubungan dengan situasi tertentu, para guru PKn SMP juga perlu menolong siswa menguji alasan yang biasa digunakan untuk mengatasi moral atau masalah moral yang ada. Para guru membantu siswa menguji pertimbangan moral yang mereka miliki dan pertimbangan orang lain dengan menyelenggarakan diskusi tentang situasi-situasi dilema.

Selanjutnya pada masa remaja awal (Usia SMP) sudah mencapai tahap operasi formal. Pada usia ini secara mental anak telah dapat berpkir logis tentang berbagai gagasan yang abstrak. Dengan kata lain, berpikir operasi formal lebih bersifat hipotesis dan abstrak serta sistematis dan ilmiah dalam memecahkan masalah daripada berpikir konkrit. Pemahaman terhadap teori Kohlberg tentang pertimbangan moral ini mengimplikasikan strategi mengajar yang khusus untuk menstimulasi perkembangan moral dalam pembelajaran PKn di SMP. Diskusi dari dilema moral akan memberikan para siswa kesempatan-kesempatan berikut:

1. Mempertimbangkan problema-problema moral sesungguhnya.

2. Mengalami konflik-konflik kognitif dan sosial sesungguhnya selama diskusi problema moral.

3. Mengaplikasikan tingkat berpikir tertentu mereka terhadap situasi-situasi problematis.

4. Terbuka terhadap tingkat berpikir berikutnya yang lebih tinggi.

5. Menghadapkan

ketidakkonsistenan pertimbangan mereka sendiri terhadap berbagai isu-isu moral tanpa seseorang yang menekankan pada jawaban benar atau salah.

Pendekatan yang digunakan baik oleh Piaget maupun oleh Kohlberg merupakan pendekatan kognitif (cognitive developmental approach to morality). Hal ini terbukti terutama dari Kohlberg yang memusatkan perhatian studinya pada aspek intelektual dari moralitas, yaitu kemampuan individu dalam melakukan penalaran terhadap suatu isu moral yang dihadapinya.

\section{KESIMPULAN}

Pendidikan Kewarganegaraan merupakan satu mata pelajaran di sekolah dasar dan menengah yang memiliki tugas profesional untuk membina siswa agar menjadi generasi penerus yang sebagaimana diharapkan bangsa dan negara dalam konteks pembinaan generasi muda menjadi seorang warga negara yang baik. Anak adalah warga negara hipotetik, yakni warga negara yang "belum jadi" karena masih harus dididik menjadi warga negara dewasa yang sadar akan hak dan kewajibannya (Budimansyah, 2007: 11). 
Sebagai wahana pendidikan formal pada jenjang pendidikan dasar dan menengah, pendidikan kewarganegaraan secara kurikuler bertujuan mengembangkan potensi peserta didik dalam seluruh dimensi kewarganegaraan, yakni; (1) pengetahuan kewarganegaraan, (2) sikap kewarganegaraan, (3) keterampilan kewarganegaraan, (4) keteguhan kewarganegaraan, (5) komitmen kewarganegaraan, (6) kompetensi kewarganegaraan (Somantri \& Winataputra, 2017: 94). Semua ranah tujuan itu harus didudukkan dalam konteks ideologisasi, instrumentasi dan aktualisasi Pancasila sebagai dasar negara, ideologi nasional, dan pandangan hidup bangsa. Oleh karena itu Pancasila harus dikonsepsikan, dimaknai, dan difungsikan sebagai entitas inti, sumber rujukan dan kriteria keberhasilan proses belajar dan pembelajaran.

\section{DAFTAR PUSTAKA}

Branson, M. S., \& Quigley, C. N. (1998). The role of civic education. Calabas: Center for Civic Education.

Budimansyah, D. (2007). Pendidikan demokrasi sebagai konteks civic education di Negaranegara berkembang. Jurnal Acta Civicus, Vol.1(No.1), 23-35.

Budimansyah, D., \& Suryadi, K. (2008). PKn dan masyarakat multikultural. Bandung: Program Studi Pendidikan Kewarganegaraan UPI.

Budiningsih, A. (2005). Belajar dan pembelajaran. Jakarta: Rineka Cipta.

Hartoonian, H. M. (1992). The social studies and project 2061: An opportunity for harmony. The Social Studies, 83(4), 160-163. https://doi.org/10.1080/00377996.1992.9956 224

Ibda, F. (2011). Perkembangan moral pada anak dan relevansinya dengan pendidikan. Jurnal Ilmiah Didaktika, XI(2), 380-391.

Kerr, D. (1999). Citizenship education : an international comparison. Practice. London: National Foundation for Education Research (NFER). Diambil dari https://www.nfer.ac.uk/research/centre-forinformation-andreviews/inca/ts citizenship education an international comparison 1999.pdf

Santrock, J. W. (2003). Adolescence (perkembangan remaja). Jakarta: Penerbit Erlangga.

Santrock, J. W. (2008). Psikologi pendidikan (2 ed.).
Jakarta: Kencana Prenada Media Grup.

Santrock, J. W. (2014). Adolescene (15 ed.). New York: McGraw-Hill Education.

Sapriya. (2007). Peran pendidikan kewarganegaraan dalam membangun karakter warga negara. Jurnal Sekolah Dasar, 16(No.1), 22-32.

Slavin, R. E. (2011). Psikologi pendidikan: Teori dan praktik (8 ed.). Jakarta: Penerbit Erlangga.

Somantri, M. N. (2001). Menggagas pembaharuan pendidikan IPS. Bandung: PT Remaja Rosda Karya.

Somantri, M. N., \& Winataputra, U. S. (2017). Disiplin pendidikan kewarganegaraan: Kultur akademis dan pedagogis. (Sapriya \& R. Machfiroh, Ed.). Bandung: Laboratorium PKn UPI.

Suparno, P. (2001). Perkembangan kognitif Jean Piaget. Yogyakarta: Kanisius.

Surya, M. (2003). Psikologi pembelajaran dan pengajaran. Bandung: Yayasan Bhakti Winaya.

Ubaidillah, A., \& Rozak, A. (2003). Pendidikan kewarganegara (civic education): Pancasila, demokrasi, hak asasi manusia, dan masyarakat madani. Jakarta: ICCE UIN Syarif Hidayatullah.

Winataputra, U. S. (2012). Pendidikan kewarganegaraan dalam perspektif pendidikan untuk mencerdaskan kehidupan bangsa. Bandung: Widya Aksara Press.

Winataputra, U. S. (2015). Pendidikan kewarganegaraan: Refleksi historis-epistemologis dan rekonstruksi untuk masa depan. Tangerang Selatan: Universitas Terbuka. 